Forest Ecology and

Management

ELSEVIER

Forest Ecology and Management 171 (2002) 87-100

www.elsevier.com/locate/foreco

\title{
Influence of soil and organic residue management on biomass and biodiversity of understory vegetation in a Eucalyptus globulus Labill. plantation
}

\author{
A. Fabião*, M.C. Martins, C. Cerveira, C. Santos, \\ M. Lousã, M. Madeira, A. Correia \\ Instituto Superior de Agronomia, Tapada da Ajuda, P-1349-017 Lisboa, Portugal
}

\begin{abstract}
The objective of this study was to assess the effect of different options of soil preparation and management of harvesting debris on biodiversity and biomass of understory vegetation in plantations of Eucalyptus globulus of Central Portugal. The experiment consisted of six treatments in a replanted area and four treatments in a coppice area with five replicates, following a randomised block design. Surveys of vegetation were performed for 6 years. The proportion of soil cover by plant species was estimated and the Shannon-Wiener diversity and equitability indexes determined for each treatment and year. After the 2nd year, the understory vegetation was randomly sampled for above-ground biomass determination. Within the planted area, the removal of slash without soil preparation induced the highest number of species during the experimental period. A similar trend was observed in the coppice area, but less regularly. Significant differences in the proportion of soil cover only occurred within the planted area in the first year, when slash removal without soil preparation induced the highest understory cover. Species diversity was not clearly affected by treatments: significant differences only occurred occasionally and were apparently related to differences in the number of species. Therefore, differences in the equitability index between treatments never were significant. Removal of slash without soil disturbance and broadcast of slash over the soil usually shared the highest biodiversity. Differences between treatments in the amount of understory biomass were never statistically significant during the experimental period. Tendency for a negative influence of soil mobilisation on the amount of understory biomass was observed within the planted area, as well as a similar effect of the treatments consisting of broadcast of slash over the soil surface in the coppice area. In parallel to tree development and canopy closure biomass of that vegetation along the study period was reduced, especially in the planted area.
\end{abstract}

(C) 2002 Elsevier Science B.V. All rights reserved.

Keywords: Biodiversity; Biomass; Equitability; Eucalyptus plantations; Site preparation; Understory

\section{Introduction}

The plantation of fast growing forest tree species has usually been established in Portugal following

\footnotetext{
* Corresponding author. Tel.: +351-21-365-3488; fax: +351-21-364-5000.

E-mail address: afabiao@isa.utl.pt (A. Fabião).
}

intensive site preparation, which causes deep soil disturbance (with variable depths according to site characteristics) and the destruction of the existing natural vegetation (Alves, 1988). These techniques may significantly reduce the amount of soil organic matter (Madeira et al., 1989), and may affect the soil water holding capacity. Planting of a fast growing tree species may have a negative effect on the reestablishment 
of natural vegetation in the understory (Alves et al., 1990). Frequently, understory species are good competitors for the fast growing tree seedlings (Alves et al., 1990; Smith et al., 1997).

Coppicing of forest tree plantations is almost always performed with the use of heavy machinery for the extraction of timber from the stand, driven by the need to increase efficiency by reducing operation costs. The use of heavy machinery may significantly increase soil compaction, mainly through alterations of the soil porosity (Lenhard, 1986). The displacement of boles and the heavy accumulation of slash on soil surface may also have an important negative effect on the reestablishment and survival of the understory vegetation (Smith et al., 1997). The consequences resulting from reduction in understory on ecosystem functions have been poorly studied.

After harvesting, slash may be removed from the site to prevent fire hazard and to ease the execution of operations during the growing stages of a stand (Smith et al., 1997). Due to the exportation and displacement of nutrients contained in plant biomass a negative effect on site fertility may occur (Nyland et al., 1979; Abbott and Crossley, 1982; Burger and Prichett, 1984; Smith et al., 1997). This may also be unfavourable to the reestablishment of understory vegetation and in some situations even to the development of the tree stratum (Smethurst and Nambiar, 1989; Emmett et al., 1991).

Therefore, fast growing forest tree plantationsand, in particular, those of Eucalyptus globulus Labill. in the Iberian Peninsula-are usually considered as having less understory vegetation than other types of forest stands or other kinds of vegetation cover (Rosa et al., 1986; Bernaldez et al., 1989; Alves et al., 1990). The judgement of value on this fact is not, however, consensual. The presence of natural vegetation is not always desirable during the early growth stages of planted forest seedlings due to competition for water and nutrients, especially where prolonged seasonal water stress is expected (Nyland, 1996; Smith et al., 1997). On the other hand, the maintenance of the understory plant cover guarantees protection against soil erosion when the stand canopy is not yet closed, and the understory contributes to the nutrient cycles and to the stability of soil aggregation (Tisdall and Oades, 1982). In addition, the natural plant cover protects young seedlings against wind and frost (Smith et al., 1997) and increases the landscape and environmental value of forested areas (Crowe, 1966, 1978; Forestry Commission, 1994). Moreover, the biodiversity of understory vegetation in intensively managed forest plantations may be an indicator for the preservation of overall biodiversity and of ecological sustainability (Bengtsson et al., 2000).

Within the above-mentioned context, it is of utmost importance to identify the effects on the understory vegetation of different methods of slash management and soil preparation at outplanting. In addition, the effects of slash disposal after coppice on subsequent understory vegetation development are poorly understood, recommending further research on the impact of alternative options of organic matter management.

The aim of this study was therefore to evaluate the effect of slash management alternatives (both in newly established and coppice plantations) and soil preparation techniques (in new plantations) on biomass and species diversity of understory vegetation in plantations of E. globulus intensively established and managed in Central Portugal. Preliminary results on biodiversity during the early growth stage (1-3 years) have already been published elsewhere (Cerveira et al., 1999), and suggest a positive effect of slash disposal, and absence or low intensity of soil disturbance, on understory species richness.

\section{Methods and materials}

\subsection{Site characteristics}

The experiment was installed at the end of March 1993 in an E. globulus plantation at Quinta do Furadouro $\left(39^{\circ} 20^{\prime} \mathrm{N}, 9^{\circ} 13^{\prime} \mathrm{W}, 30\right.$ m.a.s.l.), in West Central Portugal, ca. $10 \mathrm{~km}$ from the Atlantic Ocean. After coppice of a previous first rotation eucalyptus plantation, the stumps were killed with a systemic herbicide in part of the area (planted area) to install a new stand with eucalyptus seedlings from a single clone provenance. In the remaining area, the stumps were allowed to sprout and regenerate to form a new stand (coppice area). In both areas, the tree density was kept at approximately $1111 \mathrm{ha}^{-1}(3 \mathrm{~m} \times 3 \mathrm{~m}$ spacing $)$. In the planted area, each seedling was supplied at outplanting with ca. $100 \mathrm{~g}$ of a fertiliser containing $14 \%$ $\mathrm{N}, 16 \% \mathrm{P}$ and 17\% K (Jones et al., 1999). 
The climate of the site is of the Mediterranean type, tempered by an oceanic influence. At the weather survey station at Caldas da Raínha, ca. $12 \mathrm{~km}$ away from the site and 70 m.a.s.l., the mean annual temperature averages $15.2{ }^{\circ} \mathrm{C}$, ranging from a monthly mean of $10.4{ }^{\circ} \mathrm{C}$ in January to $19.8{ }^{\circ} \mathrm{C}$ in August. The occurrence of minimum temperatures below $0{ }^{\circ} \mathrm{C}$ is occasional. Mean annual rainfall is $607 \mathrm{~mm}$, but less than 10\% occurs between May and September. An atmospheric humidity rate usually higher than $80 \%$ in the morning, during summer, as well as frequent summer fogs, contributes to reduce the impacts of summer drought (Reis and Gonçalves, 1981).

The geology of the experimental area is dominated by Jurassic Sandstone, with fossil remains of plants and dinosaurs (Zbyszewski and Almeida, 1960). The soil is an Eutric Cambisol (FAO/UNESCO, 1988), with a base saturation level higher than $50 \%$ in the $50 \mathrm{~cm}$ top soil layer and a $\mathrm{pH}$ in water ranging from 5.2 to 5.8 in $0-80 \mathrm{~cm}$ soil (Table 1 ).

\subsection{Experimental design}

The experimental design consisted of six treatments in the planted area: (A) removal of slash without soil preparation; (B) broadcast of slash without soil preparation; (C) as in B, but depositing the woody debris between the plantation rows; (D) incorporation of slash into the soil by harrowing $(\approx 20 \mathrm{~cm}$ depth); (E) removal of slash followed by harrowing; and (F) as $\mathrm{D}$ followed by deep soil preparation with a ripper ( $\approx 50 \mathrm{~cm}$ depth).

In the coppice area, the experimental design consisted only of treatments A-D, since treatments E and $\mathrm{F}$ were considered as related to the establishment of new stands and therefore not pertinent within the context of coppice management. Within this area, the sprouts were thinned ca. 3 years after clear-cut and left on the site in all the treatments. This is the usual practice in the management of eucalyptus coppices in Portugal.

This experimental design was replicated in five different blocks in both areas. Each replicate was a plot of $30 \mathrm{~m} \times 30 \mathrm{~m}$, with a core of 36 trees $(18 \mathrm{~m} \times 18 \mathrm{~m})$ surrounded by two buffer tree rows on each of the four sides.

\subsection{Floristic surveys}

The floristic surveys were performed by the quadrat method (Kent and Coker, 1992) every spring, when the majority of plant species were flowering, from 1994 to 1999, i.e. until the stand was 6 years old. A wooden frame measuring $1 \mathrm{~m} \times 1 \mathrm{~m}$ and divided by a string in $1000.1 \mathrm{~m} \times 0.1 \mathrm{~m}$ squares was randomly applied four times in each treatment plot. All the plants inside the frame were identified to the species level (occasionally, some taxa were identified only to the genus, and some to the subspecies level). The proportion of surface cover of each species was carefully estimated and recorded.

Eucalyptus seedlings from natural regeneration by seed from the previous stand were observed and recorded as understory vegetation whenever present within the frame. A similar criterion was used for other tree species seedlings, such as Pinus radiata (natural regeneration from a neighbour stand), Lusitanian oak (Quercus faginea ssp. broteroi, with natural occurrence in the study area) and chestnut (Castanea sativa, with some isolated trees present in the neighbourhood).

Table 1

Soil characteristics of the experimental site at Quinta do Furadouro ${ }^{\mathrm{a}}$

\begin{tabular}{|c|c|c|c|c|c|c|c|c|c|c|c|}
\hline $\begin{array}{l}\text { Depth } \\
\text { (cm) }\end{array}$ & Horizon & $\begin{array}{l}\text { Bulk density } \\
\left(\mathrm{g} \mathrm{cm}^{-3}\right)\end{array}$ & $\begin{array}{l}\text { Silt } \\
\left(\mathrm{g} \mathrm{kg}^{-1}\right)\end{array}$ & $\begin{array}{l}\text { Clay } \\
\left(\mathrm{g} \mathrm{kg}^{-1}\right)\end{array}$ & $\begin{array}{l}\text { Organic } \\
\mathrm{C}\left(\mathrm{g} \mathrm{kg}^{-1}\right)\end{array}$ & $\begin{array}{l}\mathrm{pH} \\
\left(\mathrm{H}_{2} \mathrm{O}\right)\end{array}$ & $\begin{array}{l}\text { Sbase } \\
\left(\mathrm{cmol}_{\mathrm{c}} \mathrm{kg}^{-1}\right)\end{array}$ & $\begin{array}{l}\mathrm{Al} \\
\left(\mathrm{cmol}_{\mathrm{c}} \mathrm{kg}^{-1}\right)\end{array}$ & $\begin{array}{l}\text { ECEC } \\
\left(\mathrm{cmol}_{\mathrm{c}} \mathrm{kg}^{-1}\right)\end{array}$ & $\begin{array}{l}\mathrm{P} \\
\left(\mu g \mathrm{~g}^{-1}\right)\end{array}$ & $\begin{array}{l}\mathrm{K} \\
\left(\mu \mathrm{g} \mathrm{g}^{-1}\right)\end{array}$ \\
\hline $0-20$ & $\mathrm{Ah}$ & 1.47 & 23 & 161 & 8.8 & 5.24 & 1.84 & 1.90 & 3.74 & 8.6 & 120 \\
\hline $20-40$ & $\mathrm{Bw}$ & 1.52 & 25 & 198 & 7.3 & 5.19 & 2.06 & 1.73 & 3.79 & 11.4 & 69 \\
\hline $40-60$ & $\mathrm{C} 1$ & 1.54 & 18 & 172 & 2.3 & 5.62 & 2.56 & 0.72 & 4.28 & 0.7 & 71 \\
\hline $60-80$ & $\mathrm{C} 2$ & 1.63 & 11 & 130 & 1.7 & 5.81 & 1.83 & 0.53 & 2.36 & 0.7 & 61 \\
\hline
\end{tabular}

\footnotetext{
${ }^{a}$ The values represent the average of six soil profiles excavated prior to the establishment of the experiment (from Jones et al., 1999) (Sbase—sum of base cations; ECEC—effective cation exchange capacity).
} 


\subsection{Assessment of understory biomass}

A wooden frame measuring $0.5 \mathrm{~m} \times 0.5 \mathrm{~m}$ was randomly applied four times in each treatment plot, every spring from 1995 to 1999 (i.e. 2nd to 6th year), for above-ground biomass sampling. All the understory plants inside the frame were collected close to the ground and packed separately in identified plastic bags. They were immediately oven dried in the laboratory at $80-85^{\circ} \mathrm{C}$ and weighed.

\subsection{Data handling and statistical analysis}

The data from floristic surveys were compiled and organised in an Excel data-sheet (CMicrosoft) and a list of species by year and treatment plot was obtained. The soil cover proportion of each species (including the proportion of uncovered soil) in each treatment plot was averaged. The Shannon-Wiener diversity index $H$ and equitability index $J$ (Begon et al., 1996) were calculated for each treatment plot using the proportion of soil cover by each species in relation to total plant cover and e-base logarithms. The ovendry weight of understory vegetation was organised in a similar way, expressed in an area basis and integrated for each treatment plot.
The average number of species per treatment plot, the proportion of plant cover to total sampling area, the Shannon-Wiener diversity and equitability indexes and the total understory biomass were statistically compared between treatments. The SAS-System for Windows, version 6, software SAS/STAT (SAS Institute, 1989) was utilised for those comparisons. The normality of variance was verified by the Kolmogorov-Smirnov test and the homogeneity was verified through graphics of residuals (studentised residuals $\times$ predicted values) to analyse the homosedasticity of residuals and their normality. The demonstrative graphics are not shown here. Whenever the normality and homogeneity were confirmed, the comparisons were performed through the procedure GLM (generalised linear model) and the Tukey test. Blocks and treatments were considered as the independent variables and the average number of species, proportion of soil cover, diversity and equitability indexes, and biomass, the dependent variables. When variance was not normal and/or the homogeneity of residuals was not confirmed, the NPAR1WAY procedure of the same software was used and the averages were compared through the Kruskal-Wallis test. The significance level of 0.05 was utilised in all the statistical analysis of data. Homologous treatments of planted

Table 2

Average number of understory species in various treatment plots in the planted and coppice areas ${ }^{\mathrm{a}}$

\begin{tabular}{|c|c|c|c|c|c|c|}
\hline \multirow[t]{2}{*}{ Years } & \multicolumn{6}{|c|}{ Treatments } \\
\hline & A & B & $\mathrm{C}$ & $\mathrm{D}$ & $\mathrm{E}$ & $\mathrm{F}$ \\
\hline \multicolumn{7}{|c|}{ Planted area } \\
\hline 1994 & $13.4 \mathrm{a}$ & $9.0 \mathrm{a}, \mathrm{b}$ & $10.0 \mathrm{a}, \mathrm{b}$ & $10.4 \mathrm{a}, \mathrm{b}$ & $10.4 \mathrm{a}, \mathrm{b}$ & $7.6 \mathrm{~b}$ \\
\hline 1995 & 9.4 & 6.8 & 7.4 & 7.4 & 7.6 & 6.6 \\
\hline 1996 & 9.0 & 7.6 & 8.2 & 7.0 & 7.6 & 8.8 \\
\hline 1997 & 14.4 & 10.6 & 10.8 & 10.4 & 12.0 & 11.6 \\
\hline 1998 & 16.2 & 12.4 & 11.6 & 10.8 & 16.2 & 12.0 \\
\hline 1999 & 9.0 & 7.4 & 9.0 & 6.2 & 7.8 & 6.2 \\
\hline \multicolumn{7}{|c|}{ Coppice area } \\
\hline 1994 & $12.6 \mathrm{a}$ & $6.4 \mathrm{~b}$ & $6.6 \mathrm{~b}$ & 9.6a,b & - & - \\
\hline 1995 & $8.0 \mathrm{a}$ & $4.6 \mathrm{~b}$ & $5.6 \mathrm{a}, \mathrm{b}$ & $5.4 \mathrm{~b}$ & - & - \\
\hline 1996 & 7.6a,b & $3.8 \mathrm{c}$ & $4.8 \mathrm{~b}, \mathrm{c}$ & $8.2 \mathrm{a}, \mathrm{b}$ & - & - \\
\hline 1997 & 13.8 & 12.4 & 10.0 & 9.2 & - & - \\
\hline 1998 & 14.6 & 11.2 & 12.4 & 11.6 & - & - \\
\hline 1999 & $11.4 \mathrm{a}$ & $9.8 \mathrm{a}, \mathrm{b}$ & $8.6 b$ & $10.4 \mathrm{a}, \mathrm{b}$ & - & - \\
\hline
\end{tabular}

${ }^{a}$ The values followed by different characters in the same line were statistically different $(P<0.05$, GLM procedure and Tukey test). Treatments are: (A) removal of slash and plantation without soil disturbance; (B) broadcast disposal of slash and plantation without soil disturbance; (C): as in B, but with woody slash concentrated between the plantation rows; (D) incorporation of slash into the soil by harrowing; E: removal of slash followed by harrowing; F: as D followed by deep soil ripping. 

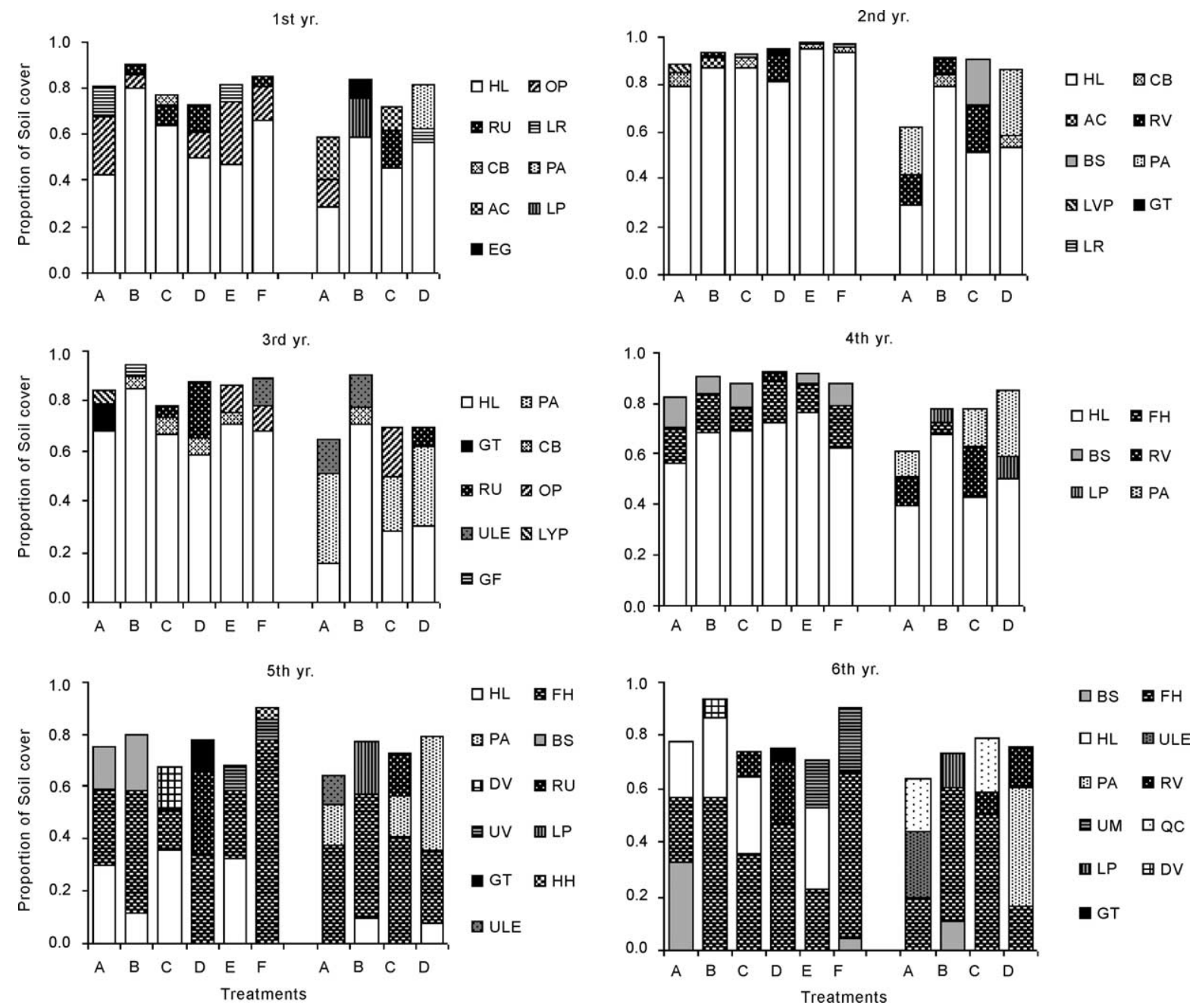

Fig. 1. Proportion of soil covered by the three more abundant understory species during different years and in different treatments. Left: planted area (A-F); right: coppice area (A-D). Treatments A-F are given in Table 2. HL: H. lanatus; OP: Ornithopus pinnatus; RU: R. ulmifolius; LR: Lepidophorum repandum; CB: Conyza bonariensis; PA: P. aquilinum; AC: Agrostis curtisii; LP: Lonicera periclymenum; EG: E. globulus; BS: Brachypodium sylvaticum; LYP: Lythrum portula; GT: Genista triacanthos; ULE: Ulex europaeus; GF: Gaudinia fragilis; FH: F. hygrometrica; DV: Dittrichia viscosa; UM: U. minor; HH: Hedera helix; QC: Q. coccifera.

and coppice areas were compared using similar statistical methods.

\section{Results and discussion}

\subsection{Number of species}

The mean total number of species per treatment plot was usually highest in the treatment A (slash removal without generalised soil disturbance), both in planted and coppice areas (Table 2). Within the planted area, however, significant differences only occurred in the first year, when treatment $\mathrm{F}$ (incorporation of slash into the soil by deep ripping) had an average number of species significantly lower than treatment A, with the remaining treatments ranking between those two.

Within the coppice area the treatment $\mathrm{A}$ had a significantly higher number of species than B and C (broadcast of slash over the soil surface, respectively 
without and with woody slash concentrated between plantation rows) in the first year, and higher than treatments B and D (incorporation of slash into the soil by harrowing) in the second. A low value also occurred in the 3rd year in treatment $\mathrm{B}$, but the highest number of species was observed in treatment $\mathrm{D}$, although its value was not significantly different from that in treatment A (cf. Table 2). The treatment A kept the highest score from the 4th to the 6th year, but significant differences only occurred in the latter year, when the treatment $\mathrm{C}$ had the lowest number of species.

In an experiment of slash management after harvest performed in coniferous forests of north-western United Sates (site characteristics and treatments described by Zabowski et al., 2000), Scherer et al. (2000) found little variation in the number of species among treatment plots, but marked differences in species composition. The treatment consisting of slash disposal over the soil surface had the lowest number of species 3 years after harvest and the dominant understory species were substantially different from those in other treatments or in non-harvested adjacent forest.

Although our experiment is hardly comparable with that described above, due to differences in site characteristics, main forest species and silvicultural techniques, we found indications of a negative influence of the presence of slash on the number of species within the coppice area. Differences in species composition among treatments, however, were not apparent during the first 4 years, neither in the planted nor in the coppice area. The proportion of understory soil cover, not accounting for bare soil, was usually dominated $(\approx 60$ to more than $90 \%)$ in all treatments by the three species that ranked first in the rank-abundance diagrams (not shown in this article), along the study period (Fig. 1). The grass coloniser Holcus lanatus was dominant in almost all the treatments of both planted and coppice areas along the first 4 years, except for treatments A, C and D of the coppice in the 3rd year. From the 4th year onwards a moss, Funaria hygrometrica, became one the most abundant species in almost all the treatments of both areas, being strongly dominant in treatments $\mathrm{B}, \mathrm{D}$ and $\mathrm{F}$ (planted area) and A, B and C (coppice area) in the 5th year. In the 6th year, $F$. hygrometrica ranked first in treatments B, C, D and F (planted area) and B and C (coppice area) suggesting a relationship with the pre- sence of slash, either distributed over the soil, or incorporated into the topsoil by harrowing or deep soil ripping. Its presence in treatments consisting of slash removal (A and E) was, however, still important and that relationship was not clear. The change in species composition might also be a consequence of environmental changes at the understory level due to canopy closure after the 4th year, as discussed below. In some treatments of both areas, woody perennials strongly increased their relative importance during the 6th year. Genista triacanthus (treatment D of the planted area), Ulex minor (treatments $\mathrm{E}$ and $\mathrm{F}$ of the same area), U. europaeus (A, coppice area), Quercus coccifera (A and C, coppice area) and Rubus ulmifolius (C and D, both areas) are good examples of such a tendency.

Bracken (Pteridium aquilinum) was the second most abundant species in treatment $\mathrm{D}$ of the coppice area in the first 2 years, and in treatment $A$ in the 2 nd year. It dominated in the understory plant cover of $\mathrm{A}$ and $\mathrm{D}$ during the 3 rd year (when it ranked second in treatment C), to decrease again in the 4th (Fig. 2). Until the end of the experiment it never was within the three most abundant species in treatment B (broadcast of slash over the soil surface) of the coppice area, neither an important species in the planted area (cf. Fig. 1). Dolling (1999) studied bracken in hemiboreal forests of southern Sweden and concluded that this species was suppressed under closed canopy, but the rhizomes could survive for several years. The presence of intact rhizomes may be the key factor for its spreading after clear-cutting or in forest clearings, as it apparently happened in our experiment after coppice. The proportion of soil cover by bracken in treatment $\mathrm{D}$, where this species was abundant since the beginning, increased with time, suggesting that the incorporation of slash into the soil by harrowing might have positively affected its survival and subsequent spreading. The removal of organic soil layers and the absence of soil disturbances in treatment A also had a positive effect on the spreading of bracken until the 3rd year, but its importance decreased after that, in apparent agreement with the above-mentioned suppression due to canopy closure.

The coppice area usually had a lower number of understory species than the planted area, but an inverse situation occasionally occurred in all treatments from the 3 rd year onwards. Significant differences 


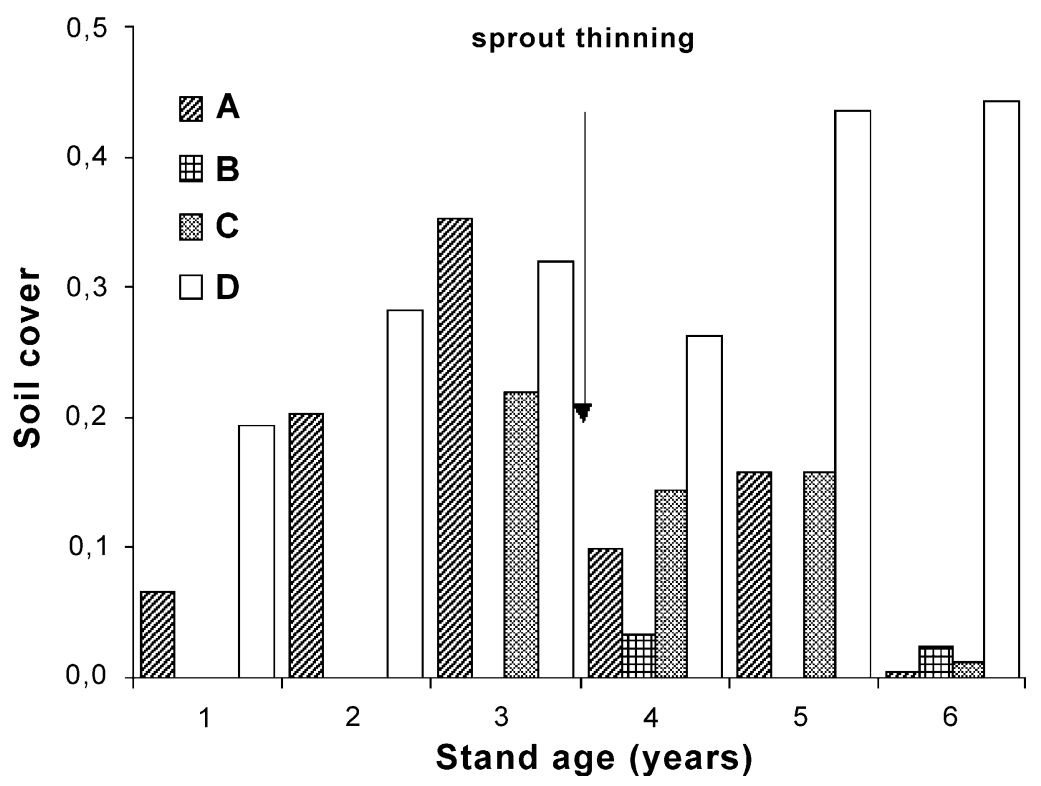

Fig. 2. Proportion of soil covered by bracken (P. aquilinum) in treatments of the coppice area along the experimental period. Treatments A-D are given in Table 2 .

between these areas only occurred in treatment $\mathrm{C}$ in the first year and in treatment $\mathrm{D}$ in the 2nd and 6th years, in the latter year with the highest number of species in the coppice area.

The average number of species followed the same general trend over the experimental period, irrespective of treatment or area, planted or coppice (Table 2). This is in agreement with Moore and Allen (1999), who stated that the richness of understory species in forest plantations did not usually decrease as a consequence of management practices, at least prior to crown closure. Our results also suggest that the number of species present in the understory vegetation reflected, at least partially, the scarcity or abundance of winter and spring rainfall in different years, with the highest scores in the rainy years and the lowest in the dry ones. The experimental area in 1993-1994, 19951996 and 1997-1998 received an amount of winter and spring rainfall higher than the 50-year average 1941-1990, whereas 1994-1995 and 1998-1999 hardly totalled more than half that average (Francisco Abreu, pers. commun.). Spring rainfall (March-May) in 1995 was less than half the 50-year average. We may speculate that the 1994-1995 drought may have contributed to a decrease in the number of species in the 2nd and 3rd years of the experiment, although the latter had a high amount of rainfall. The recovery of species richness in 1997 and 1998 was paralleled with normal and high rainfall in 1996-1997 and 19971998. The decrease in the number of species observed in 1999, a dry year, may also be dependent on changes due to stand development.

The results also suggest that species richness was affected by the intensity of the initial perturbations resulting from tree harvest, slash disposal, and/or soil preparation (the latter mainly within the planted area). In the planted area, the lowest number of species was always observed in treatments consisting of incorporation of slash into the soil, both by surface harrowing (treatment D, during the 3rd to 6th year period) and deep ripping (treatment $\mathrm{F}$, in the 1st, 2nd and 6th years).

In the coppice area the treatment D had the highest number of species in the 3rd year. The lowest score only occurred in this treatment in the 4th year, when species richness was exceptionally high in all the treatments of both areas (probably as a consequence of abundant rainfall in spring). On the other hand, the treatments consisting of distribution of slash over the soil surface usually had the lowest number of species, and frequently differences were statistically significant in relation to treatment A and/or D. 
This different pattern between coppice and planted areas may have resulted from differences in tree cover and management techniques. Early tree growth was faster in the coppice than in the planted area (Jones et al., 1999), and in the former the sprouts were thinned and abandoned over the soil in all the treatments between the 3 rd and 4th years.

\subsection{Proportion of soil cover}

Within the planted area, the lowest proportions of understory plant cover were observed in treatments $\mathrm{C}$ (1st to 4th years), $\mathrm{F}$ (consisting of incorporation of slash by ripping, in the 5th year) and $\mathrm{E}$ (removal of slash followed by harrowing, in the 6th year) (Table 3). The observed differences were statistically significant only in the 1st year, with treatments A and E (consisting of removal of slash, respectively without and with soil disturbance) being significantly different from $\mathrm{C}$ (consisting of broadcast of leaf and bark residues left on the soil surface).

The differences between treatments were not significant for the coppice area, but treatment B had the lowest values between the 1 st and the 5th years and treatment $\mathrm{D}$ in the 6th. In the first year, the treatment $\mathrm{D}$ had the highest proportion of understory vegetation cover, but the difference to treatment A was negligible. Treatment A ranked the first between the 2nd and 4th years, but decreased after that, ranking below treatments $\mathrm{D}$ and $\mathrm{C}$ in the 5 th year and below $\mathrm{C}$ in the 6 th, when the experiment finished.

The coppice area consistently showed lower proportion of understory vegetation cover than the planted area during the first 3 years of the experiment (cf. Table 3). Such differences were statistically significant $(P<0.05)$ in treatment $\mathrm{A}$ in the first 2 years, in treatment $B$ in the first 3 years and in treatment $D$ in the 2nd year. Although not significant in the 4th to 6th years, treatments $\mathrm{A}$ and $\mathrm{B}$ kept those differences during the experiment period. The treatment $\mathrm{C}$, however, had higher soil cover in the coppice than in the planted area from the 4th to the 6th year, and treatment $\mathrm{D}$ in the 5th and 6th years (with a very small difference in the latter year), but these differences were not statistically significant $(P>0.05)$.

The treatment A usually had the highest proportion of understory plant cover in both areas. The exceptions occurred in the 4th year in the planted area (when treatment $\mathrm{F}$ had the highest value, followed by $\mathrm{D}$ and A). In the 1st and 5th years in the coppice area, the highest values were in treatment $\mathrm{D}$, and in 6th year in treatment $\mathrm{C}$.

Table 3

Average proportion (\% of total area, including uncovered soil) of understory plant cover in treatment plots in the planted and coppice areas ${ }^{\mathrm{a}}$

\begin{tabular}{|c|c|c|c|c|c|c|}
\hline \multirow[t]{2}{*}{ Years } & \multicolumn{6}{|c|}{ Treatments } \\
\hline & A & B & $\mathrm{C}$ & $\mathrm{D}$ & $\mathrm{E}$ & $\mathrm{F}$ \\
\hline \multicolumn{7}{|c|}{ Planted area } \\
\hline 1994 & $95.4 \mathrm{a}$ & 72.9a,b & $51.1 \mathrm{~b}$ & $70.0 \mathrm{a}, \mathrm{b}$ & $95.0 \mathrm{a}$ & $82.0 \mathrm{a}, \mathrm{b}$ \\
\hline 1995 & 93.7 & 88.9 & 53.1 & 78.0 & 81.2 & 82.3 \\
\hline 1996 & 71.2 & 65.9 & 56.2 & 61.8 & 67.7 & 71.0 \\
\hline 1997 & 96.75 & 95.55 & 80.65 & 99.15 & 83.90 & 105.75 \\
\hline 1998 & 91.68 & 65.18 & 48.33 & 55.45 & 42.58 & 39.39 \\
\hline 1999 & 87.05 & 62.20 & 63.10 & 39.60 & 26.8 & 40.00 \\
\hline \multicolumn{7}{|c|}{ Coppice area } \\
\hline 1994 & 52.7 & 26.4 & 42.5 & 54.1 & - & - \\
\hline 1995 & 51.7 & 32.7 & 51.5 & 43.7 & - & - \\
\hline 1996 & 56.8 & 20.2 & 55.9 & 49.1 & - & - \\
\hline 1997 & 91.30 & 77.90 & 88.25 & 82.00 & - & - \\
\hline 1998 & 60.26 & 41.40 & 62.06 & 65.10 & - & - \\
\hline 1999 & 59.81 & 58.02 & 66.70 & 40.18 & - & - \\
\hline
\end{tabular}

${ }^{\mathrm{a}}$ The values of the planted area followed by different characters in the same line were statistically different $(P<0.05$, GLM procedure and Tukey test). The differences between treatments of the coppice area were not statistically significant $(P>0.05$, NPAR1WAY procedure $)$. Treatments are given in Table 2. 
Usually a decrease in understory plant cover should be expected after canopy closure, eventually occurring together with a change in species composition (Nyland, 1996; Spies, 1997; Barnes et al., 1998; Brokaw and Lent, 1999). Yorks and Dabydeen (1999) observed a decline in understory cover following clear-cut in hardwood mixed forests of Maryland, USA. The canopy closure in E. globulus plantations may result in a sudden decrease in crown depth (increasing the extension of bare stem), and a stabilisation in the leaf area index (LAI) (Pereira et al., 1997). In our experiment, this occurred approximately in the 4th year, as expected in E. globulus plantations in moderate to good quality sites in Portugal (Pereira et al., 1997). The thinning of sprouts in the coppice area did not delay the canopy closure, since the remaining stems had a very fast growth response following thinning.

Despite the qualitative changes that occurred in understory species composition between the 4th and 5 th years, a clear decrease in vegetative cover with stand development was not observed in this experiment. On the contrary, almost all the treatments had the highest cover in the 4 th year, i.e. about the canopy closure stage (Table 3). The exception was treatment E of the planted area, which had the highest proportion of plant cover in the 1 st year. The plant cover increase in the 4th year may result from either spring rainfall above the local average, or the high contribution of $F$. hygrometrica and bracken to understory cover. The small vertical growth of $F$. hygrometrica contrasts with its wide horizontal spreading, leading to the development of a very low continuous moss stratum over the soil. Bracken, on the other hand, formed a higher stratum that frequently allowed the development of other herbaceous plants under its cover.

\subsection{Shannon-Wiener diversity and equitability indexes}

Within the planted area, the relationship between treatments on Shannon-Wiener diversity index was not clear (Table 4). Significant differences between treatments only occurred in the 1 st and 4 th years. In the 1st year, treatments $\mathrm{D}$ and $\mathrm{E}$ had higher diversity than treatment $\mathrm{B}$, with $\mathrm{A}, \mathrm{C}$ and $\mathrm{F}$ scoring intermediate values. In the 4 th year, treatment $A$ had a significantly higher Shannon-Wiener diversity index than treatment E, and all the other treatments ranked between those two. In the other years, the highest value was in treatments A (2nd year), C (3rd and 5th years) and E (6th year), defying any attempt of interpretation.

In the coppice area, a difference similar to that observed in the planted area occurred in the 4th year, but between treatments $\mathrm{A}$ and $\mathrm{D}$. The latter ranked as the second lowest in the planted area in the same year, but the difference to treatment A was not statistically significant. The differences between treatments of the coppice area were not significant in other years. Treatment A usually ranked the highest index values in all years except the 3rd and 6th year, when treatment D scored the highest Shannon-Wiener diversity indexes. The lowest value for diversity was in treatment $\mathrm{D}$ in the 1st, 2nd and 4th years, in treatment $\mathrm{B}$ in the 3rd year, and in treatment $C$ in the 5 th and 6th year.

With the exception of treatment $\mathrm{C}$ and sometimes of treatment $\mathrm{D}$, there was a tendency for higher values of the diversity index in the coppice than in the planted area, but the difference was significant only for treatment $\mathrm{A}$ in the 2 nd year $(P<0.05)$. In contrast, treatment $C$ had a Shannon-Wiener diversity index significantly higher in the planted than in the coppice area in the 5th year $(P<0.01)$. Treatment $\mathrm{C}$ had a higher diversity index in the planted than in the coppice area in the 1st, 3rd and 6th years, and the treatment $\mathrm{D}$ in the 1 st year, but the differences were not significant.

Most of the differences in the diversity index may probably be related to differences in the average number of species in each treatment and in each year. The differences between treatments in the equitability index (Table 5) were never significant, either in the planted or in the coppice areas. The highest values in the planted area were observed in treatments E (1st and 6th years), C (2nd, 3rd and 5th years) and A (4th year). In the coppice area, treatment A ranked the highest value in the 1st, 2nd and 4th years, but in other years the maximum was shared between treatments $C$ (3rd year), D (5th year) and B (6th year).

With the exception of treatment $D$ in the 1st year (not significantly different) and $\mathrm{C}$ in the 5th year $(P<0.05)$ and 6th years (not significantly), the coppice area always had higher Shannon-Wiener equitability indexes than the planted area. However, the 
Table 4

Shannon-Wiener diversity index in treatment plots in the planted and coppice areas ${ }^{\mathrm{a}}$

\begin{tabular}{|c|c|c|c|c|c|c|}
\hline \multirow[t]{2}{*}{ Year } & \multicolumn{6}{|c|}{ Treatments } \\
\hline & & B & $\mathrm{C}$ & $\mathrm{D}$ & $\mathrm{E}$ & $\mathrm{F}$ \\
\hline \multicolumn{7}{|c|}{ Planted area } \\
\hline 1994 & $1.082 \mathrm{a}, \mathrm{b}$ & $0.695 b$ & $1.210 \mathrm{a}, \mathrm{b}$ & $1.259 \mathrm{a}$ & $1.254 \mathrm{a}$ & $0.941 \mathrm{a}, \mathrm{b}$ \\
\hline 1995 & 0.784 & 0.514 & 0.751 & 0.475 & 0.295 & 0.307 \\
\hline 1996 & 0.949 & 0.580 & 1.027 & 0.785 & 0.828 & 0.848 \\
\hline 1997 & $1.106 \mathrm{a}$ & $0.751 \mathrm{a}, \mathrm{b}$ & $0.716 a, b$ & $0.679 a, b$ & $0.608 \mathrm{~b}$ & $0.766 a, b$ \\
\hline 1998 & 1.293 & 1.047 & 1.559 & 1.120 & 1.407 & 0.959 \\
\hline 1999 & 0.926 & 0.747 & 1.205 & 0.777 & 1.213 & 0.663 \\
\hline \multicolumn{7}{|c|}{ Coppice area } \\
\hline 1994 & 1.549 & 1.092 & 1.119 & 1.082 & - & - \\
\hline 1995 & 1.171 & 0.745 & 0.900 & 0.740 & - & - \\
\hline 1996 & 1.054 & 0.627 & 0.804 & 1.287 & - & - \\
\hline 1997 & $1.138 \mathrm{a}$ & $1.039 \mathrm{a}, \mathrm{b}$ & $0.787 \mathrm{a}, \mathrm{b}$ & $0.740 \mathrm{~b}$ & - & - \\
\hline 1998 & 1.531 & 1.355 & 1.241 & 1.361 & - & - \\
\hline 1999 & 1.321 & 1.350 & 0.933 & 1.352 & - & - \\
\hline
\end{tabular}

${ }^{a}$ The values followed by different characters in the same line were statistically different $(P<0.05$, GLM procedure and Tukey test). Treatments are given in Table 2.

differences only were significant for treatment $\mathrm{A}$ in the 2nd year $(P<0.05)$, similar to that observed in the diversity index.

Moore and Allen (1999) stated that, in intensively managed forest plantations, complete removal of canopy through harvesting produces a more diverse flora than that occurring under a closed canopy. Site preparation activities tend to reduce diversity in the short term, but the duration of that impact depends on the intensity of those practices. In our experiment, we expected some kind of temporal trend in diversity of understory vegetation, even if differences among treatments were not clear or merely speculative. Both diversity and equitability decreased from the first to

Table 5

Shannon-Wiener equitability index in treatment plots in the planted and coppice areas ${ }^{\mathrm{a}}$

\begin{tabular}{|c|c|c|c|c|c|c|}
\hline \multirow[t]{2}{*}{ Year } & \multicolumn{6}{|c|}{ Treatments } \\
\hline & A & B & $\mathrm{C}$ & $\mathrm{D}$ & $\mathrm{E}$ & $\mathrm{F}$ \\
\hline \multicolumn{7}{|c|}{ Planted area } \\
\hline 1994 & 0.424 & 0.331 & 0.526 & 0.537 & 0.546 & 0.461 \\
\hline 1995 & 0.359 & 0.275 & 0.384 & 0.231 & 0.156 & 0.159 \\
\hline 1996 & 0.470 & 0.294 & 0.495 & 0.457 & 0.420 & 0.403 \\
\hline 1997 & 0.422 & 0.314 & 0.306 & 0.298 & 0.248 & 0.315 \\
\hline 1998 & 0.471 & 0.456 & 0.651 & 0.460 & 0.502 & 0.391 \\
\hline 1999 & 0.438 & 0.345 & 0.550 & 0.416 & 0.599 & 0.377 \\
\hline \multicolumn{7}{|c|}{ Coppice area } \\
\hline 1994 & 0.617 & 0.588 & 0.611 & 0.490 & - & - \\
\hline 1995 & 0.578 & 0.486 & 0.560 & 0.433 & - & - \\
\hline 1996 & 0.533 & 0.471 & 0.542 & 0.622 & - & - \\
\hline 1997 & 0.438 & 0.416 & 0.361 & 0.335 & - & - \\
\hline 1998 & 0.570 & 0.569 & 0.497 & 0.597 & - & - \\
\hline 1999 & 0.546 & 0.588 & 0.438 & 0.578 & - & - \\
\hline
\end{tabular}

${ }^{a}$ The differences between treatments were not statistically significant $(P>0.05$, GLM procedure). Treatments are given in Table 2 . 

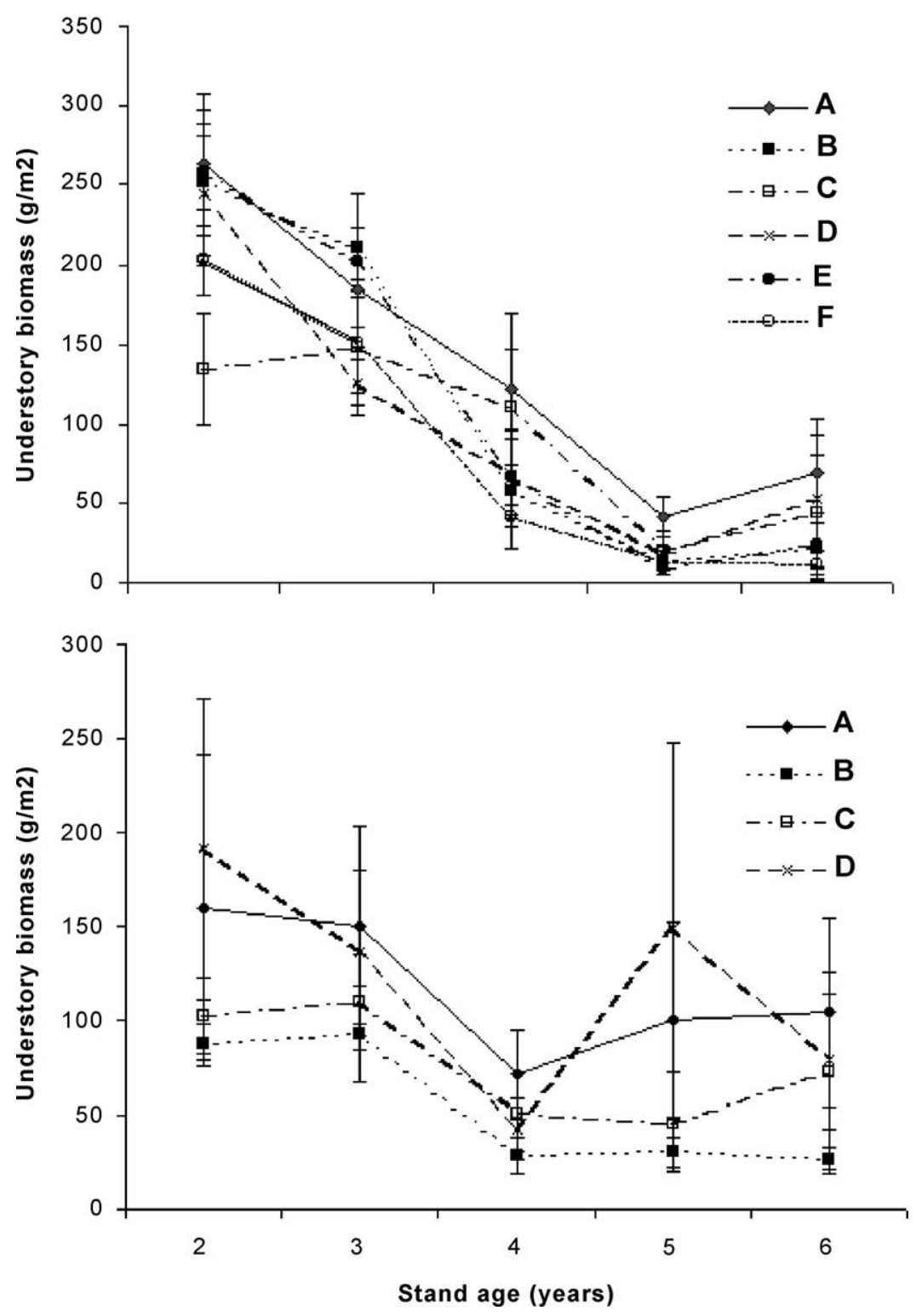

Fig. 3. Variation over time of the understory biomass from the 2 nd to the 6 th year of the experiment in the treatments of the planted (top) and coppice (bottom) areas. The vertical bars represent \pm 1 S.E. The differences between treatments were not statistically significant $(P>0.05$, NPAR1WAY procedure). Treatments A-F are given in Table 2.

the 2nd year and in some treatments the 3 rd or the 4 th year, either in planted or in coppice area, but there was a clear increase in the 5th year in all treatments and areas (Tables 4 and 5). This temporal pattern does not match with any defined temporal trend in flora composition. Yorks and Dabydeen (1999), who studied understory diversity in second-growth hardwood for- ests of Maryland, USA, also found an overall absence of any significant trend in diversity with stand age. Apparently, differences in environmental characteristics such as aspect and the dominance of single understory species in particular sites had greater influence in diversity than the stand age. Dominance of the understory cover by a small number of species 
was also observed in our study in all treatments and both experimental areas.

Removal of slash followed by deep soil disturbance is probably the most common technique of site preparation to establish eucalypt plantations in Portugal. It has been demonstrated that intensive soil preparation is not always needed for plantation success or for wood production optimisation (Madeira et al., 1989). The current experiment showed that tree growth was not significantly affected by treatments on this site (Jones et al., 1999). It may be therefore possible to decrease the intensity of site preparation in favourable environmental situations, for adequate development of understory biodiversity and for wood production.

\subsection{Biomass}

The understory biomass generally decreased during the experimental period in all treatments, both in the planted and coppice areas, but the decrease was less regular in the latter. In most treatments, however, there was a small increase between the 5th and the 6th year, especially within the planted area (Fig. 3). Therefore, the variation of understory biomass with stand age matched the expected pattern of decline over time, following stand development from establishment to canopy closure. The particular development pattern of F. hygrometrica on the proportion of understory plant cover was not found in the biomass, due to the negligible contribution of $F$. hygrometrica to the total understory biomass.

Differences in biomass between treatments were not significant, neither in the planted nor in the coppice areas. Within the planted area, the lowest biomass occurred in one of the treatments consisting of some type of soil disturbance (D and E, by harrowing, respectively with and without incorporation of slash, and F, by ripping). The only exception was treatment $\mathrm{C}$, which scored the lowest value in the 2nd year. The highest understory biomass was always found in treatment A (2nd and 4th to 6th years) and, exceptionally, in treatment B (3rd year, when treatment A ranked the third).

Within the coppice area the highest understory biomass was found in treatments A (3rd, 4th and 6th years) or D (2nd and 5th years) and the lowest consistently in treatment B. This pattern differed from that shown by the treatments of the planted area, where treatment $\mathrm{B}$ also ranked the lowest of treatments A-D (i.e., excluding treatments $\mathrm{E}$ and F), but only during the last 3 years of the experimental period.

The biomass data suggest that broadcast disposal of slash over the soil surface might have inhibited the development of understory vegetation in the coppice area, especially when woody biomass components (branches and twigs) were also included. A possible reason for that inhibition might have been soil shading by woody slash disposal. It may be speculated, however, whether competition for nitrogen between understory vegetation and decomposing woody debris could also have an effect on the development of understory biomass (M.C. Magalhães, pers. commun.). Within the planted area, as referred above, it was soil disturbance that apparently had the highest contribution to a decrease of understory biomass, but in the last 3 years of the experimental period treatment $\mathrm{B}$ also ranked the last of treatments A-D.

\section{Conclusions}

The mean total number of species per treatment plot was high when slash was removed without soil disturbance, both in planted and coppice areas. This trend was clearer for the coppice than the planted area. In the planted area, incorporation of slash into the soil, with or without subsoil disturbance, induced the lowest number of species. This trend, however, was not observed in the coppice area.

Decrease in species richness during the early stage of stand growth followed drought conditions, both during the year and in spring. The highest proportion of understory plant cover was promoted when slash was removed without soil disturbance, both in planted and coppice areas.

The Shannon-Wiener diversity and equitability indexes did not show a clear relationship with treatments. The diversity and, especially, equitability index were higher in the coppice than in the planted area. Understory biomass decreased with time in the planted area during the first 5 years of the experiment. This decrease was not observed in the coppice area. Broadcast distribution of slash on the soil surface 
negatively affected understory biomass in coppice area. Data at the end of the experimental period suggest that the development of shrubs may be responsible for changes in the understory biomass.

\section{Acknowledgements}

The experiment was funded by EU (Project CEC AIR-CT-92-0492), JNICT/FCT, Portugal (Projects PDGT/FER/366/94 and PRAXIS XXI 3/3.2/FLOR/ 2123/95), and PAMAF Program (Ministry of Agriculture), Portugal (Project 4029/95). Maria do Céu Martins, Cláudia Cerveira and Conceição Santos were granted, as graduation students and/or junior scientists, by JNICT/FCT. The pulp company Celulose Beira Industrial (CELBI), S.A., landowner of Quinta do Furadouro, supervised the management of the experimental area. The contribution of two anonymous referees to the improvement of the manuscript is gratefully acknowledged.

\section{References}

Abbott, D.T., Crossley Jr., D.A., 1982. Woody litter decomposition following clear-cutting. Ecology 63, 35-42.

Alves, A.A.M., 1988. Técnicas de Produção Florestal. Fundamentos, Tipificação e Métodos, $2^{\mathrm{a}}$ edição. Instituto Nacional de Investigação Científica, Lisboa.

Alves, A.A.M., Pereira, J.M.S., Borges, J.G.C., Borges, G.C., Carvalho, P.O., David, J.S., Gonçalves, J.H.C., Madeira, M., Onofre, N., Valente, F., 1990. Impactes Ambientais e SócioEconómicos do Eucaliptal em Portugal. Departamento de Engenharia Florestal, Universidade Técnica de Lisboa, Instituto Superior de Agronomia, Lisboa.

Barnes, B.V., Zak, D.R., Denton, S.R., Spurr, S.H., 1998. Forest Ecology, 4th ed. Wiley, New York.

Begon, M., Harper, J.L., Townsend, C.R., 1996. Ecology, 3rd ed. Blackwell Science, Oxford.

Bengtsson, J., Nilsson, S.G., Franc, A., Menozzi, P., 2000. Biodiversity, disturbances, ecosystem function and management of European forests. For. Ecol. Manage. 132, 39-50.

Bernaldez, F.G., Perez, R.P., Levassor, C., 1989. Effets des Plantations d'Eucalyptus dans le Nord d'Espagne. Commission des Communautés Européennes, Brussels.

Brokaw, N.V., Lent, R.A., 1999. Vertical structure. In: Hunter Jr., M.L. (Ed.), Maintaining Biodiversity in Forest Ecosystems. Cambridge University Press, Cambridge, pp. 373-399.

Burger, J.A., Prichett, W.L., 1984. Effects of clearfelling and site preparation on nitrogen mineralization in a southern pine stand. Soil Sci. Soc. Am. J. 48, 1432-1437.
Cerveira, C., Lousã, M., Fabião, A., Madeira, M., Tomé, M., 1999. Influência de técnicas de instalação e condução do eucaliptal na diversidade da vegetação sob coberto. Revista de Ciências Agrárias XXII (2), 49-63.

Crowe, S., 1966. Forestry in the Landscape. Forestry Commission Booklet No. 18. Her Majesty's Stationery Office, London.

Crowe, S., 1978. The Landscape of Forests and Woods. Forestry Commission Booklet No. 44. Her Majesty's Stationery Office, London.

Dolling, A., 1999. The vegetative spread of Pteridium aquilinum in a hemiboreal forest-invasion or revegetation. For. Ecol. Manage. 124, 177-184.

Emmett, B.A., Anderson, J.M., Hornung, M., 1991. Nitrogen sinus following two intensities of harvesting in a Sitka spruce forest (N. Wales) and the effect on the establishment of the next cropping. For. Ecol. Manage. 41, 81-93.

FAO/UNESCO, 1988. Soil Map of the World (revised legend). FAO, Rome.

Forestry Commission, 1994. Forest Landscape Design Guidelines. Her Majesty's Stationery Office, London.

Jones, H.E., Madeira, M., Herraez, L., Dighton, J., Fabião, A., González-Rio, F., Fernandez-Marcos, M., Gomez, C., Tomé, M., Feith, H., Magalhães, M.C., Howson, G., 1999. The effect of organic matter management on the productivity of Eucalyptus globulus stands in Spain and Portugal: tree growth and harvest residue decomposition in relation to site and treatment. For. Ecol. Manage. 122, 73-86.

Kent, M., Coker, P., 1992. Vegetation Description and Analysis: A Practical Approach. Belhaven Press, London.

Lenhard, R.J., 1986. Change in void distribution and volume during compaction of a forest soil. Soil Sci. Soc. Am. J. 50, 462464.

Madeira, M., Melo, G., Alexandre, C., Steen, E., 1989. Effects of deep ploughing and superficial disc harrowing on physical and chemical soil properties and biomass in a new plantation of Eucalyptus globulus. Soil Till. Res. 14, 163-175.

Moore, S.E., Allen, H.L., 1999. Plantation forestry. In: Hunter Jr., M.L. (Ed.), Maintaining Biodiversity in Forest Ecosystems. Cambridge University Press, Cambridge, pp. 400-433.

Nyland, R.D., 1996. Silviculture: Concepts and Applications. Forestry Series. McGraw-Hill, New York.

Nyland, R.D., Leaf, A.L., Bickelhaut, D.H., 1979. Litter removal impairs growth of direct seeded Norway spruce. For. Sci. 25, 244-246.

Pereira, J.M.C., Tomé, M., Carreiras, J.M.B., Tomé, J.A., Pereira, J.S., David, J.S., Fabião, A.M.D., 1997. Leaf area estimation from tree allometrics in Eucalyptus globulus plantations. Can. J. For. Res. 27, 166-173.

Reis, R.M., Gonçalves M.Z., 1981. Caracterização Climática da Região Agrícola do Ribatejo e Oeste. O Clima de Portugal. Fasc. XXXII. Instituto Nacional de Meteorologia e Geofísica, Lisboa.

Rosa, M.L., Gomes, M.F., Espírito-Santo, M.D., 1986. Influência de factores ecológicos e fitotécnicos na Flora espontânea de sistemas florestais da região de Castelo Branco. In: 1 Congresso Florestal Nacional. Fundação Calouste Gulbenkian, Lisboa, pp. 255-260. 
SAS Institute, 1989. SAS/STAT User Guide, vol. II, Version 6, 4th ed. SAS Institute, Cary, NC.

Scherer, G., Zabowski, D., Java, B., Everett, R., 2000. Timber harvesting residue treatment. Part II. Understory vegetation response. For. Ecol. Manage. 126, 35-50.

Smethurst, P.J., Nambiar, E.S.K., 1989. Role of weeds in the management of nitrogen in a young Pinus radiata plantation. New For. 3, 203-224

Smith, D.M., Larson, B.C., Kelty, M.J., Ashton P.M.S., 1997. The Practice of Silviculture: Applied Forest Ecology, 9th ed. Wiley, New York.

Spies, T., 1997. Forest stand structure, composition and function. In: Kohm, K.A., Franklin, J.F. (Eds.), Creating a Forestry for the 21st Century: The Science of Ecosy- stem Management. Island Press, Washington, DC, pp. 1130.

Tisdall, J.M., Oades, J.M., 1982. Organic matter and water stable aggregates in soils. J. Soil Sci. 33, 141-163.

Yorks, T.E., Dabydeen, S., 1999. Seasonal and successional understory vascular plant diversity in second-growth hardwood clearcuts of western Maryland, USA. For. Ecol. Manage. 119, 217-230.

Zabowski, D., Java, B., Scherer, G., Everett, R.L., Ottmar, R., 2000. Timber harvesting residue treatment. Part I. Responses of conifer seedlings, soils and microclimate. For. Ecol. Manage. 126, 25-34.

Zbyszewski, G., Almeida F.M., 1960. Carta Geológica de Portugal (Esc. 1:50 000). Notícia Explicativa da Folha 26-D. Serviços Geológicos de Portugal, Lisboa. 